\title{
Crop Switching and Farm Sustainability: Empirical Evidence from Multinomial Treatment-Effect Modeling
}

\author{
Yir-Hueih Luh *(D), Yun-Cih Chang and Shuay-Tsyr Ho *(D)
}

Department of Agricultural Economics, National Taiwan University, Taipei 10617, Taiwan; f08627010@ntu.edu.tw * Correspondence: yirhueihluh@ntu.edu.tw (Y.-H.L.); shuaytsyrho@ntu.edu.tw (S.-T.H.)

\begin{abstract}
Crop switching has been examined in the literature addressing the production effects of irrigation or as viable strategy in the adaptation to climate change, which is closely related to agricultural resilience. Attention to the identification of the direct linkage between crop switching and farm profitability, and, thus, farm sustainability, however, has been quite limited. This study attempts to provide a significant complement to the extant research by identifying the treatment effect of crop switching on the net returns of crop growers in Taiwan. A multinomial endogenous treatment effects model with the latent-factor structure is used to take self-selection into account. The result suggests that farm households' economic resilience is closely related to their choice of crops, which constitute the major source of farm income. Specifically, among the six cash crop categories, fruit crops and other crops are found to be most remunerating and, thus, suggests possible improvements in farm households' economic resilience through crop switching. A further analysis of the distributional implications of crop switching through quantile regression confirms the persistent and stronger effects of crop choice on net returns when moving from the bottom to the top quartiles along the net-return distribution. This result suggests a close association of crop choices with farm income inequality among the crop farm households in Taiwan, which in turn implies possible distributional effects of crop switching.
\end{abstract}

Citation: Luh, Y.-H.; Chang, Y.-C.; Ho, S.-T. Crop Switching and Farm Sustainability: Empirical Evidence from Multinomial Treatment-Effect Modeling. Sustainability 2022, 14, 1422. https://doi.org/10.3390/ su14031422

Academic Editor: Antonio Boggia

Received: 20 December 2021

Accepted: 24 January 2022

Published: 26 January 2022

Publisher's Note: MDPI stays neutral with regard to jurisdictional claims in published maps and institutional affiliations.

Copyright: (c) 2022 by the authors. Licensee MDPI, Basel, Switzerland. This article is an open access article distributed under the terms and conditions of the Creative Commons Attribution (CC BY) license (https:// creativecommons.org/licenses/by/ Keywords: crop switching; farm sustainability; economic resilience; multinomial treatments; farmhousehold analysis

\section{Introduction}

Most of the research on the sustainability of agriculture focused their attention on mitigating the environmental impacts of agricultural production. However, the adoption of environmentally friendly production schemes alone may not ensure the sustainable development of the rural economy. In recent years, strategies to building and/or strengthening agricultural resilience have been viewed as crucial in the process of adaptation to climate change.

To build agricultural resilience, the Australian Drought Resilience Funding Plan identifies three strategic priorities, including (1) economic resilience (i.e., an innovative and profitable agricultural sector); (2) environmental resilience (i.e., sustainable farming landscapes); and (3) social resilience (resourceful and adaptable rural communities) [1]. Since a smallholder's capability to overcome periods of downturns will increase once sufficient returns are generated, the causal effect of resilience-building options on a smallholder's net returns can serve as a good indicator for the contribution of the viable options to economic resilience. The present study attempts to provide a significant complement to the extant research on agricultural resilience by applying the multinomial treatment-effects-modelling approach to the identification of the causal effect of one of the climate change adaptation strategies—crop switching-on farm households' economic resilience, and possible distributional implications. 
The present research is motivated by our observation that despite the significance of crop choice as one of farm households' production strategies that is closely related to household welfare [2], attention to the identification of the direct causal effect of crop switching on farm households' income or net returns has been quite limited. The only exception may have been previous research [3] which investigated the relationship between crop choice and farm income through a decomposition of the income by crops. Crop choice has been examined in the literature addressing the production effects of irrigation [4] and production-related choices in the adaptation to climate change [5-9]. For instance, based on a structural Ricardian model, African farmers were found to exhibit crop-switching behavior in their adaptation to extreme weather due to climate change [6]. In a study with surface water as a production input, e.g., [4], crop choices and land allocation were jointly modeled as individual farmer's production decisions. A parallel strand of a previous study focused on investigating the determinants of crop choice. In the examination of the driving factors of crop choice in the agricultural heritage system [10], the determinants of crop choice were found to vary with the categories of the rural households. A study on Ethiopia [11] pinpointed the importance of irrigation potentials on farmers' crop choices. Similarly, the availability of irrigation was found to play an important role in Bangladeshi farmers' adoption of the modern rice variety [12]. However, weather shocks were found to be the major determinant for Nigerian and Ugandan farmers' crop-choice decisions [13]. One important topic related to crop choice is the spatial change of the major grain production in response to weather shocks [14]. A study on China echoed the remarkable changes in crop type and spatial pattern and found spatial crop switching from wheat and barley to corn and rapeseed [15].

The aims of this study are two-fold. The first research focus of the present study is to analyze the determinants of crop choice and to assess the causal effect of crop choice on economic resilience. To this end, we use large-scale and population-based farm-household data, drawn from the primary farm households (PFHs) survey in Taiwan. The use of the farm-household-level data in Taiwan to reach this research aim is relevant since one unique characteristic of the PFHs is that more than $90 \%$ of the 150,000 households are growers of cash crops, including rice, vegetables, fruits, specialty crops, grains, and other crops. Examination of the economic outcomes resulting from crop switching, with a reference to the contribution of crop choice to agricultural resilience and farm sustainability, can, thus, render important implications of farm-household welfare.

The second research aim of this study concerns the distributional implications of crop switching. It was indicated that the "economy wide benefits of a broad-based, agricultural growth strategy that reduce inequality would likely be high" [16] (p. 147), and more equitable growth is, thus, expected to lead to higher social welfare gains which can enhance the resilience of the agricultural sector. However, to our knowledge, research focused on the examination of the association of crop choice with income inequality has been sparse. The only exception may have been the research of [3], which found that the major source of agriculture income for households in the top quintile is from sugarcane and other crops, whereas those in the bottom quintile received the largest share from wheat and rice, suggesting the differential effects of cash and food crops on inequality. The identification of the contribution of crop choice to farm income inequality may, thus, provide a significant complement to the existing body of research. Using the quantile-regression approach, the present study adds to the literature through our investigation of welfare implications of crop switching to farm households in Taiwan.

This paper is organized as what follows. The next section lays out the empirical specifications, including the multinomial treatment effect model and the source of data used in this study, followed by the empirical results and an in-depth discussion of the results. The last section concludes this study. 


\section{Materials and Methods}

\subsection{Data Source}

The data source used in the present research is taken from the 2013 survey of the Primary Farm Households (PFHs) in Taiwan. Relative to the agricultural census data, PFHs are larger and younger since they are sampled from the population of 150,000 households which have an annual income of more than NT\$200,000 and at least one member who is no older than 65 years old. There is a total of 9951 farm households in the dataset. After deleting noncrop farm households, the final dataset used in this study has 9328 observations.

The descriptive statistics of the data are listed in Table 1 . The average level of net re-turns is around NT $\$ 509,600$. With a share of $89 \%$, farm households are dominated by male operators. On average, the operators are 57 years old and have 30 years of farming experience. Farm operators' educational levels are generally low since approximately $65 \%$ of the farm operators have elementary school or junior high school degrees. Prior to working on their own farms, approximately $47 \%$ of the farm operators did not have a full-time job. The average on-farm workdays for the principal operators are 237 days, and more than $90 \%$ of the farm households have at least one member participating in farmers organizations. Small-scale farm operations are common considering household labor and farmland size. The order of the geographical distributions of the farm households are central $(48 \%)$, south $(33 \%)$, north $(12 \%)$, and east $(0.07 \%)$.

Table 1. Variable definitions and descriptive statistics (full sample).

\begin{tabular}{cccc}
\hline Variable & Definition & Mean & Std Dev \\
\hline Net returns & Farm income-production costs, in NT\$1000 & 509.57 & 581.3719 \\
Male & Gender of major farm operator & 0.89 & 0.31 \\
Age & Age of major farm operator & 57.26 & 10.91 \\
Experience & Farm operator's farming experience & 29.27 & 14.7 \\
Edu1 & Education (elementary school \& below) & 0.38 & 0.49 \\
Edu2 & Education (junior high school) & 0.27 & 0.45 \\
Edu3 & Education (senior high school) & 0.29 & 0.45 \\
Edu4 & Education (college and above) & 0.06 & 0.24 \\
Prior1 & Previous work: agriculture employee & 0.06 & 0.24 \\
Prior2 & Previous work: manufacturing, business, service, etc. & 0.37 & 0.48 \\
Prior3 & Previous work: Self-employed & 0.1 & 0.47 \\
Prior4 & Previous work: none & 237.11 & 0.3 \\
Days & Days of work on farm (annual base) & 0.9 & 70.01 \\
Farmer Org. & Membership in farmers' organizations & 0.3 \\
HH_Labor & Household members working on farm & 2.53 & 1.03 \\
Land & Land size of the farm & 92.89 & 102.47 \\
North & Household district area: north & 0.12 & 0.32 \\
Central & Household district area: central & 0.48 & 0.5 \\
South & Household district area: south & 0.33 & 0.47 \\
East & Household district area: east & 0.26 \\
\hline
\end{tabular}

By-crop statistics are listed in Table 2. Notable differences are observed in net returns with by-crop average net returns in order as other crop (NT\$2,142,000), vegetable crops (NT\$974,000), fruit crops (NT\$861,000), rice $(\mathrm{NT} \$ 739,000)$, grains (NT\$647,000), and specialty crops $(\mathrm{NT} \$ 375,000)$. Specialty crops are generally defined as fruits and vegetables and nursery and greenhouse crops. However, our category "Specialty" here represents the specialized commodity crops besides fruits and vegetables, considering that fruit and vegetable itself are worthwhile to be treated as single category for closer examination. The principal operators' days of on-farm work reveal a different order for the six crop categories in order as other crop, vegetable, grains, fruit, specialty crops, and rice. Another notable difference concerns the geographical distribution. Except for the specialty crop category, all 
the other five crop categories are located in the central and southern areas. Most of the farm households producing specialty crops, however, are located in central and eastern Taiwan.

Table 2. By-crop descriptive statics.

\begin{tabular}{|c|c|c|c|c|c|c|}
\hline Variable & Rice & Vegetable & Fruit & Specialty & Grains & Other \\
\hline \multicolumn{7}{|c|}{ Outcome variable } \\
\hline Net returns & $\begin{array}{c}739.34 \\
(952.26)\end{array}$ & $\begin{array}{c}973.62 \\
(1194.23)\end{array}$ & $\begin{array}{c}860.72 \\
(910.77)\end{array}$ & $\begin{array}{c}375.36 \\
(616.32)\end{array}$ & $\begin{array}{c}647.22 \\
(427.39)\end{array}$ & $\begin{array}{c}2142.09 \\
(3338.57)\end{array}$ \\
\hline \multicolumn{7}{|l|}{ Farm operator } \\
\hline Male & $\begin{array}{c}0.92 \\
(0.28)\end{array}$ & $\begin{array}{c}0.9 \\
(0.30)\end{array}$ & $\begin{array}{c}0.88 \\
(0.33)\end{array}$ & $\begin{array}{c}0.89 \\
(0.31)\end{array}$ & $\begin{array}{c}0.81 \\
(0.39)\end{array}$ & $\begin{array}{c}0.93 \\
(0.26)\end{array}$ \\
\hline Age & $\begin{array}{c}58.75 \\
(10.98)\end{array}$ & $\begin{array}{c}57.2 \\
(11.24)\end{array}$ & $\begin{array}{c}57.85 \\
(10.83)\end{array}$ & $\begin{array}{c}55.1 \\
(9.99)\end{array}$ & $\begin{array}{l}59.86 \\
(9.02)\end{array}$ & $\begin{array}{l}54.87 \\
(10.45)\end{array}$ \\
\hline Experience & $\begin{array}{c}30.78 \\
(15.88)\end{array}$ & $\begin{array}{c}29.57 \\
(15.34)\end{array}$ & $\begin{array}{c}29.48 \\
(14.77)\end{array}$ & $\begin{array}{c}28.81 \\
(12.10)\end{array}$ & $\begin{array}{c}36.22 \\
(15.03)\end{array}$ & $\begin{array}{c}26.86 \\
(12.65)\end{array}$ \\
\hline Edu1 & $\begin{array}{c}0.44 \\
(0.50)\end{array}$ & $\begin{array}{c}0.43 \\
(0.49)\end{array}$ & $\begin{array}{c}0.37 \\
(0.48)\end{array}$ & $\begin{array}{c}0.29 \\
(0.45)\end{array}$ & $\begin{array}{c}0.64 \\
(0.48)\end{array}$ & $\begin{array}{l}0.27 \\
(0.44)\end{array}$ \\
\hline Edu2 & $\begin{array}{c}0.25 \\
(0.43)\end{array}$ & $\begin{array}{c}0.3 \\
(0.46)\end{array}$ & $\begin{array}{c}0.27 \\
(0.44)\end{array}$ & $\begin{array}{c}0.32 \\
(0.46)\end{array}$ & $\begin{array}{c}0.16 \\
(0.37)\end{array}$ & $\begin{array}{c}0.26 \\
(0.44)\end{array}$ \\
\hline Edu3 & $\begin{array}{c}0.24 \\
(0.43)\end{array}$ & $\begin{array}{c}0.24 \\
(0.43)\end{array}$ & $\begin{array}{c}0.3 \\
(0.46)\end{array}$ & $\begin{array}{c}0.33 \\
(0.47)\end{array}$ & $\begin{array}{c}0.19 \\
(0.39)\end{array}$ & $\begin{array}{c}0.35 \\
(0.48)\end{array}$ \\
\hline Edu4 & $\begin{array}{c}0.06 \\
(0.24)\end{array}$ & $\begin{array}{c}0.04 \\
(0.19)\end{array}$ & $\begin{array}{c}0.06 \\
(0.23)\end{array}$ & $\begin{array}{c}0.07 \\
(0.26)\end{array}$ & $\begin{array}{c}0.02 \\
(0.13)\end{array}$ & $\begin{array}{c}0.12 \\
(0.32)\end{array}$ \\
\hline Prior1 & $\begin{array}{c}0.07 \\
(0.25)\end{array}$ & $\begin{array}{c}0.07 \\
(0.25)\end{array}$ & $\begin{array}{c}0.06 \\
(0.24)\end{array}$ & $\begin{array}{c}0.02 \\
(0.14)\end{array}$ & $\begin{array}{c}0.05 \\
(0.21)\end{array}$ & $\begin{array}{c}0.06 \\
(0.23)\end{array}$ \\
\hline Prior2 & $\begin{array}{c}0.39 \\
(0.49)\end{array}$ & $\begin{array}{c}0.38 \\
(0.49)\end{array}$ & $\begin{array}{c}0.37 \\
(0.48)\end{array}$ & $\begin{array}{c}0.33 \\
(0.47)\end{array}$ & $\begin{array}{c}0.28 \\
(0.45)\end{array}$ & $\begin{array}{c}0.34 \\
(0.47)\end{array}$ \\
\hline Prior3 & $\begin{array}{c}0.09 \\
(0.29)\end{array}$ & $\begin{array}{c}0.09 \\
(0.29)\end{array}$ & $\begin{array}{c}0.10 \\
(0.31)\end{array}$ & $\begin{array}{c}0.10 \\
(0.30)\end{array}$ & $\begin{array}{c}0.06 \\
(0.24)\end{array}$ & $\begin{array}{c}0.10 \\
(0.30)\end{array}$ \\
\hline Prior4 & $\begin{array}{c}0.45 \\
(0.50)\end{array}$ & $\begin{array}{c}0.46 \\
(0.50)\end{array}$ & $\begin{array}{c}0.46 \\
(0.50)\end{array}$ & $\begin{array}{c}0.55 \\
(0.50)\end{array}$ & $\begin{array}{c}0.61 \\
(0.49)\end{array}$ & $\begin{array}{c}0.50 \\
(0.50)\end{array}$ \\
\hline Days & $\begin{array}{c}191.3 \\
(72.28)\end{array}$ & $\begin{array}{l}247.33 \\
(64.90)\end{array}$ & $\begin{array}{c}234.7 \\
(68.26)\end{array}$ & $\begin{array}{c}227.8 \\
(62.49)\end{array}$ & $\begin{array}{l}246.66 \\
(77.32)\end{array}$ & $\begin{array}{l}266.11 \\
(60.57)\end{array}$ \\
\hline Farmer Org. & $\begin{array}{c}0.93 \\
(0.26)\end{array}$ & $\begin{array}{c}0.9 \\
(0.31)\end{array}$ & $\begin{array}{c}0.91 \\
(0.29)\end{array}$ & $\begin{array}{c}0.88 \\
(0.33)\end{array}$ & $\begin{array}{c}0.78 \\
(0.42)\end{array}$ & $\begin{array}{c}0.89 \\
(0.32)\end{array}$ \\
\hline HH_Labor & $\begin{array}{c}2.5 \\
(1.03)\end{array}$ & $\begin{array}{c}2.57 \\
(1.01)\end{array}$ & $\begin{array}{c}2.51 \\
(1.02)\end{array}$ & $\begin{array}{c}2.37 \\
(1.13)\end{array}$ & $\begin{array}{c}2.84 \\
(1.22)\end{array}$ & $\begin{array}{l}2.73 \\
(1.16)\end{array}$ \\
\hline Land & $\begin{array}{c}137.78 \\
(127.10)\end{array}$ & $\begin{array}{c}70.2 \\
(78.56)\end{array}$ & $\begin{array}{c}108.93 \\
(107.12)\end{array}$ & $\begin{array}{c}97.7 \\
(106.51)\end{array}$ & $\begin{array}{l}111.22 \\
(72.89)\end{array}$ & $\begin{array}{c}57.71 \\
(70.86)\end{array}$ \\
\hline North & $\begin{array}{c}0.1 \\
(0.30)\end{array}$ & $\begin{array}{c}0.17 \\
(0.38)\end{array}$ & $\begin{array}{c}0.08 \\
(0.26)\end{array}$ & $\begin{array}{c}0.2 \\
(0.40)\end{array}$ & $\begin{array}{c}0.02 \\
(0.13)\end{array}$ & $\begin{array}{c}0.06 \\
(0.23)\end{array}$ \\
\hline Central & $\begin{array}{c}0.4 \\
(0.49)\end{array}$ & $\begin{array}{c}0.51 \\
(0.50)\end{array}$ & $\begin{array}{c}0.44 \\
(0.50)\end{array}$ & $\begin{array}{c}0.52 \\
(0.50)\end{array}$ & $\begin{array}{c}0.72 \\
(0.45)\end{array}$ & $\begin{array}{c}0.82 \\
(0.38)\end{array}$ \\
\hline South & $\begin{array}{c}0.34 \\
(0.47)\end{array}$ & $\begin{array}{c}0.28 \\
(0.45)\end{array}$ & $\begin{array}{c}0.43 \\
(0.49)\end{array}$ & $\begin{array}{c}0.03 \\
(0.18)\end{array}$ & $\begin{array}{c}0.17 \\
(0.38)\end{array}$ & $\begin{array}{c}0.11 \\
(0.31)\end{array}$ \\
\hline East & $\begin{array}{c}0.16 \\
(0.37)\end{array}$ & $\begin{array}{c}0.03 \\
(0.18)\end{array}$ & $\begin{array}{c}0.06 \\
(0.24)\end{array}$ & $\begin{array}{c}0.25 \\
(0.43)\end{array}$ & $\begin{array}{c}0.09 \\
(0.29)\end{array}$ & $\begin{array}{c}0.01 \\
(0.12)\end{array}$ \\
\hline $\begin{array}{c}\text { No. of } \\
\text { observation }\end{array}$ & 1156 & 2734 & 4186 & 600 & 64 & 588 \\
\hline
\end{tabular}

Note: Figures in the parenthesis are standard deviations.

\subsection{Identification Strategy}

It is assumed that the farm operator's crop choices are based on the expected profitmaximization framework (see, for instance, $[6,7,17]$ ). Our identification strategy follows the multinomial endogenous treatment-effect model [18]. Let the $i$ th farm operator's expected 
profits from the $m$ th crop choice be denoted by $E_{i}\left(\pi^{m}\right), m=1, \ldots, M$. Assume further that $\alpha$ is the parameter vector, the expected profit is a linear function of the farm operator and operator's observed characteristics $(x), E_{i}\left(\pi^{m}\right)=x_{i} \alpha_{m}+\varepsilon_{i m}$, and the farm operator will choose crop $k$ if

$$
E_{i}\left(\pi^{k}\right)>E_{i}\left(\pi^{m}\right) \text { for all } m \neq k\left[\text { or } \varepsilon_{i m}-\varepsilon_{i k}<x_{i} \alpha_{k}-x_{i} \alpha_{m} \text { for all } m \neq k\right]
$$

Denote the $k$ th crop choice by the indicator variable, $C_{i k}$, the probability that the $k$ th crop choice is made can then be expressed as

$$
\operatorname{Prob}\left[C_{i k}=1 \mid x_{i}\right]=\operatorname{Prob}\left[E_{i}\left(\pi^{k}\right)>E_{i}\left(\pi^{m}\right)\right] \text { for all } m \neq k
$$

Let the latent variables be denoted by $C_{i k}^{l}$, with the factor loadings denoted by $\delta_{k}$. Under the assumption that $\left(\varepsilon_{i 1}, \ldots, \varepsilon_{i M}\right)$ follows a multinomial logistic distribution, and there are unobservable characteristics affecting both the outcome and the crop choice, the probability that the $i$ th farm operator chooses the $k$ th crop choice can be expressed as:

$$
\operatorname{Prob}\left[C_{i k}=1 \mid x, C^{l}, \alpha, \delta\right]=\frac{\exp \left(x_{i}^{\prime} \alpha_{k}+\delta_{k} C_{i k}^{l}\right)}{\sum_{m=1}^{M} \exp \left(x_{i}^{\prime} \alpha_{m}+\delta_{m} C_{i m}^{l}\right)}
$$

This study then starts out with the outcome equation of the farm operator's crop choices. Since the crop choices are mutually exclusive and exhaustive, the economic outcome of the crop choices can be expressed as the following,

$$
N R_{i}=\beta_{0}+z_{i} \kappa+\beta_{1} C_{i 1}+\beta_{2} C_{i 2}+\ldots+\beta_{M} C_{i M}+u_{i}
$$

In the above equation, $N R_{i}$ denotes the $i$ th farm household's net revenue from crop farming, and $C_{i k}$ and $\beta_{k}$ are, respectively, the $k$ th crop choice and its corresponding parameter. The vector of explanatory variables other than crop choice, including the socio-economic variables capturing the observed characteristics of the farm operators and households, is denoted by $z$. The vector of parameters for $z$ is denoted by $\kappa$.

Since the farm operator's crop choices may be correlated with the disturbance term, $\mu_{i}$, estimates obtained from (4) will be biased. The unaddressed endogeneity issues in (4) may undermine its validity by ignoring the possibility that farmers themselves may have nonrandom decision criteria to grow certain crops that could lead to higher returns afterwards. The unobserved characteristics that may allocate farmers into different crop choice scenarios, such as financial capability, knowledge of farming/ranching, social capital, entrepreneurship traits, network of marketing channels for particular crop sales, or farming condition and environmental constraints, may lead to a self-selection problem in estimating the causal relationship between crop choice and net returns.

To correct for this endogeneity problem, the expected value of the outcome equation is expressed as:

$$
E\left(N R_{i} \mid z, C, C^{l}, \kappa, \beta, \lambda\right)=\gamma_{0}+z_{i}^{\prime} \kappa+\sum_{k} \beta_{k} C_{i k}+\sum_{k} \lambda_{k} C_{i k}^{l}
$$

In (5), the latent factor of the choice of crop $k, C_{i k}^{l}$, is included in the net returns equation to capture the unobservable characteristics determining both crop choice and its economic outcome. The coefficient of the $k$ th latent factor is denoted by $\lambda_{k}$, which is the selection term revealing the correlation between the unobservable determinants of the treatment and outcome equations [18]. The empirical strategy here is different from the instrumental variable approach and the Heckman selection model by considering the same set of unobserved factors affecting both crop choice and economic returns, with the corresponding coefficients in the net return equation representing its correlation with farm households' crop choice. 
Under the above identification strategy, the endogeneity issue concerning crop choice is addressed through the maximization of the log-likelihood function of the joint distribution of crop choices and net returns, conditioned on a set of common latent variables. The major estimation problem encountered in the joint estimation of the treatment and outcome equations is that the latent factors common to the two equations are unobservable. This estimation problem can be resolved using the simulation-based estimation procedure [19]. The simulation-based estimation is to maximize the simulated log-likelihood function of the joint distribution of crop choices and net returns in which latent factors are simulated using pseudorandom numbers generated from the assumed joint distribution of the latent variables.

\section{Results and Discussion}

The PFHs are categorized by the major crop grown on the farm, including rice, vegetables, fruits, specialty crops, grains, and other crops. The multinomial treatment-effects model estimates the crop-choice and net-returns-determining equations simultaneously. We report the estimates of the multinomial treatment-effects model with the fruit households as the reference group while controlling for the farm/household as well as the major operator's characteristics in Tables 3 and 4. Table 3 reports the estimates for the treatment, i.e., crop choice, while Table 4 reports the estimates for the treatment effect which are the effect of crop choice on net returns. The estimates of crop choice reported in Table 3 are interpreted in a relative sense, i.e., the coefficient of one predictor in the $k$ th crop choice is a measure of the effect of the predictor on the probability of choosing the $k$ th crop over the reference group.

The results in Table 3 indicate the differential influence of each socioeconomic factor. With the exception of grain growers, male farm operators are more inclined to a choice from the other four crop categories. Similarly, younger and more experienced farm operators are more likely to choose rice, vegetables, specialty crops, and grains as their major crop relative to choosing fruit crops. There are also diversified patterns of crop choice among different educational groups. Relative to those with an elementary school (or below) education, farm operators with higher level of education are more likely to choose specialty and other crops while less likely to choose the other three crop categories.

The influence of the industry in which the farm operator worked prior to entering the farm business reveals the opposite case. For specialty crops, coefficients associated with farm operators' previous work experience are significant and negative across all prior work industries, indicating that for farm operators who were employed prior to entering the farm business, the log-odds of choosing specialty crops over fruit crops are predicted to be lower while holding constant all the other variables in the model. The other two variables involving farm operators' characteristics are farm operators' days of farm work (on an annual base) and membership in farmers' organizations, including farmers' associations, agricultural cooperatives, and production-marketing teams. The principal farm operators' days of on-the-farm work are found to reduce the log-odds of farm operators' choice of rice and specialty crops relative to the choice of fruit crops, whereas the log-odds of choosing vegetables and other crops increases with the operators' on-farm workdays. However, membership in farmers' organizations is found to work in the opposite direction: membership increases (reduces) the log-odds of choosing rice (grains and other crops) as the major crop.

There are three types of farm-household characteristics considered in the present study, which include farm-household size in terms of household labor and farmland area and the geographical location of the farm household. Although the results in Table 3 indicate the unanimous positive effects of the farm households' own labor and farm sizes on the log-odds of choosing crops other than fruit, the effect of land area used for crop farming tends to affect the log-odds in an opposite way except for rice. It is found that, farm households devoting more land to farming are less likely to choose vegetable, grains, and other crops as the major crops. The effect of geographical locations, however, is found 
to exhibit different influences on the households' crop choices. The negative coefficient for the north area indicates that farm households located in northern Taiwan are more likely to choose fruit crops. While the households located in central Taiwan have a higher probability of choosing rice, specialty crops, and grains as the major crops; those located in the south are less likely to grow rice, vegetables, and specialty crops relative to the other crop categories.

Table 3. Multinomial treatment model estimates (crop choice).

\begin{tabular}{|c|c|c|c|c|c|}
\hline Variable & Rice & Vegetable & Specialty & Grains & Other \\
\hline Male & $\begin{array}{c}0.799 * * * \\
(0.141)\end{array}$ & $\begin{array}{c}0.353 * * * \\
(0.099)\end{array}$ & $\begin{array}{l}0.290 * \\
(0.167)\end{array}$ & $\begin{array}{l}-0.260 \\
(0.348)\end{array}$ & $\begin{array}{c}0.417^{* *} \\
(0.196)\end{array}$ \\
\hline Age & $\begin{array}{c}-0.014^{* *} \\
(0.006)\end{array}$ & $\begin{array}{c}-0.028^{* * *} \\
(0.005)\end{array}$ & $\begin{array}{c}-0.037^{* * *} \\
(0.008)\end{array}$ & $\begin{array}{c}-0.074^{* * *} \\
(0.025)\end{array}$ & $\begin{array}{l}-0.008 \\
(0.008)\end{array}$ \\
\hline Experience & $\begin{array}{l}0.009^{*} \\
(0.005)\end{array}$ & $\begin{array}{c}0.004 \\
(0.004)\end{array}$ & $\begin{array}{c}0.024^{* * *} \\
(0.007)\end{array}$ & $\begin{array}{l}0.057^{* *} \\
(0.025)\end{array}$ & $\begin{array}{c}-0.012 \text { * } \\
(0.007)\end{array}$ \\
\hline Edu2 & $\begin{array}{c}-0.401 * * * \\
(0.115)\end{array}$ & $\begin{array}{c}-0.372 * * * \\
(0.087)\end{array}$ & $\begin{array}{c}0.337^{* *} \\
(0.149)\end{array}$ & $\begin{array}{c}-1.268^{* * *} \\
(0.421)\end{array}$ & $\begin{array}{c}0.114 \\
(0.153)\end{array}$ \\
\hline Edu3 & $\begin{array}{c}-0.664^{* * *} \\
(0.132)\end{array}$ & $\begin{array}{c}-0.863^{* * *} \\
(0.099)\end{array}$ & $\begin{array}{c}0.264 \\
(0.172)\end{array}$ & $\begin{array}{c}-1.205^{* * *} \\
(0.449)\end{array}$ & $\begin{array}{c}0.388^{* *} \\
(0.168)\end{array}$ \\
\hline Edu4 & $\begin{array}{c}-0.452 \text { ** } \\
(0.198)\end{array}$ & $\begin{array}{c}-1.043^{* * *} \\
(0.165)\end{array}$ & $\begin{array}{c}0.627^{* *} \\
(0.256)\end{array}$ & $\begin{array}{c}-1.906^{*} \\
(1.011)\end{array}$ & $\begin{array}{c}1.382^{* * *} \\
(0.234)\end{array}$ \\
\hline Prior1 & $\begin{array}{c}0.127 \\
(0.169)\end{array}$ & $\begin{array}{l}-0.024 \\
(0.125)\end{array}$ & $\begin{array}{c}-1.296 \text { *** } \\
(0.327)\end{array}$ & $\begin{array}{l}-0.339 \\
(0.624)\end{array}$ & $\begin{array}{l}-0.248 \\
(0.236)\end{array}$ \\
\hline Prior2 & $\begin{array}{l}0.176^{*} \\
(0.103)\end{array}$ & $\begin{array}{c}0.093 \\
(0.078)\end{array}$ & $\begin{array}{c}-0.447^{* * *} \\
(0.136)\end{array}$ & $\begin{array}{c}0.138 \\
(0.321)\end{array}$ & $\begin{array}{c}-0.733^{* * *} \\
(0.144)\end{array}$ \\
\hline Prior3 & $\begin{array}{c}-0.302 \\
(0.157)\end{array}$ & $\begin{array}{l}-0.006 \\
(0.112)\end{array}$ & $\begin{array}{c}-0.334 \text { * } \\
(0.194)\end{array}$ & $\begin{array}{c}0.181 \\
(0.534)\end{array}$ & $\begin{array}{l}-0.240 \\
(0.199)\end{array}$ \\
\hline Days & $\begin{array}{c}-0.012 * * * \\
(0.001)\end{array}$ & $\begin{array}{c}0.004^{* * *} \\
(0.001)\end{array}$ & $\begin{array}{c}-0.004^{* * *} \\
(0.001)\end{array}$ & $\begin{array}{c}0.002 \\
(0.002)\end{array}$ & $\begin{array}{c}0.008^{* * *} \\
(0.001)\end{array}$ \\
\hline Farmer Org. & $\begin{array}{c}0.549^{* * *} \\
(0.150)\end{array}$ & $\begin{array}{l}-0.125 \\
(0.102)\end{array}$ & $\begin{array}{l}-0.140 \\
(0.164)\end{array}$ & $\begin{array}{c}-1.404^{* * *} \\
(0.326)\end{array}$ & $\begin{array}{c}-0.305^{*} \\
(0.166)\end{array}$ \\
\hline HH_labor & $\begin{array}{l}-0.060 \\
(0.042)\end{array}$ & $\begin{array}{c}0.116^{* * *} \\
(0.030)\end{array}$ & $\begin{array}{l}-0.072 \\
(0.059)\end{array}$ & $\begin{array}{c}0.239 * * \\
(0.109)\end{array}$ & $\begin{array}{c}0.318^{* * *} \\
(0.049)\end{array}$ \\
\hline Land & $\begin{array}{l}0.003^{* * *} \\
(<0.001)\end{array}$ & $\begin{array}{c}-0.007^{* * *} \\
(0.001)\end{array}$ & $\begin{array}{c}-0.001 \\
(0.001)\end{array}$ & $\begin{array}{c}0.001 \\
(0.001)\end{array}$ & $\begin{array}{c}-0.011^{* * * *} \\
(0.001)\end{array}$ \\
\hline Central & $\begin{array}{c}-0.253^{*} \\
(0.147)\end{array}$ & $\begin{array}{c}-0.968^{* * *} \\
(0.097)\end{array}$ & $\begin{array}{c}-0.906^{* * *} \\
(0.136)\end{array}$ & $\begin{array}{c}2.197^{* *} \\
(1.016)\end{array}$ & $\begin{array}{c}0.868^{* * *} \\
(0.206)\end{array}$ \\
\hline East & $\begin{array}{c}1.241^{* * *} \\
(0.183)\end{array}$ & $\begin{array}{c}-1.765^{* * *} \\
(0.164)\end{array}$ & $\begin{array}{c}0.532 * * * \\
(0.176)\end{array}$ & $\begin{array}{c}2.137^{* *} \\
(1.083)\end{array}$ & $\begin{array}{c}-1.547^{* * *} \\
(0.455)\end{array}$ \\
\hline South & $\begin{array}{c}-0.546^{* * *} \\
(0.149)\end{array}$ & $\begin{array}{c}-1.464^{* * *} \\
(0.100)\end{array}$ & $\begin{array}{c}-3.794^{* * *} \\
(0.267)\end{array}$ & $\begin{array}{c}0.773 \\
(1.041)\end{array}$ & $\begin{array}{c}-1.122^{* * * *} \\
(0.241)\end{array}$ \\
\hline Constant & $\begin{array}{c}0.489 \\
(0.419)\end{array}$ & $\begin{array}{c}1.565 * * * \\
(0.320)\end{array}$ & $\begin{array}{l}1.326^{* *} \\
(0.510)\end{array}$ & $\begin{array}{c}-2.983^{* *} \\
(1.475)\end{array}$ & $\begin{array}{c}-3.899 * * * \\
(0.557)\end{array}$ \\
\hline
\end{tabular}

Notes: 1. Fruit crop is the control group (base category). 2. Figures in the parenthesis are robust standard errors. 3. Total obs $=9328$, Wald chi2 $(101)=3232.80, \operatorname{Prob}>\operatorname{chi} 2<0.0001 .4{ }^{*}{ }^{* * *}$ and ${ }^{* * *}$ denote significant at the $10 \%, 5 \%$, and $1 \%$ significance levels. 
Table 4. Multinomial treatment model estimates (net returns).

\begin{tabular}{|c|c|c|c|c|}
\hline \multirow{2}{*}{ Variable } & \multicolumn{2}{|c|}{ Multinomial Treatment } & \multicolumn{2}{|c|}{ OLS } \\
\hline & Estimate & SE & Estimate & SE \\
\hline Rice & $-140.62 * * *$ & 21.54 & $-112.85^{* * *}$ & 17.20 \\
\hline Vegetable & $-29.52 * *$ & 14.11 & 20.36 * & 11.69 \\
\hline \multicolumn{5}{|l|}{ Fruit (reference) } \\
\hline Specialty & $-353.56^{* * *}$ & 20.59 & $-289.70^{* * *}$ & 16.44 \\
\hline Grains & $-224.36^{* * *}$ & 23.84 & $-252.89^{* * *}$ & 23.39 \\
\hline Other & $498.21^{* * *}$ & 45.67 & $520.69 * * *$ & 45.74 \\
\hline Male & $47.36^{* * *}$ & 14.50 & $43.98^{* * *}$ & 14.38 \\
\hline Age & $-5.69^{* * *}$ & 0.95 & $-5.45^{* * *}$ & 0.94 \\
\hline Experience & $1.04 *$ & 0.63 & 0.99 & 0.62 \\
\hline Edu2 & 13.77 & 14.88 & 15.49 & 14.69 \\
\hline Edu3 & $44.75^{* * *}$ & 17.21 & $49.82 * * *$ & 17.17 \\
\hline Edu4 & 55.95 & 36.17 & $60.70 *$ & 36.32 \\
\hline Prior1 & -26.18 & 19.60 & -24.29 & 19.61 \\
\hline Prior2 & $-73.81^{* * *}$ & 15.42 & $-73.65^{* * *}$ & 15.42 \\
\hline Prior3 & -34.12 & 22.01 & -33.36 & 21.98 \\
\hline Days & $1.11^{* * *}$ & 0.08 & $1.10^{* * *}$ & 0.08 \\
\hline Farmer Org. & $52.09 * * *$ & 16.71 & $52.32 * * *$ & 16.58 \\
\hline HH_Labor & $60.97^{* * *}$ & 6.61 & $60.72 * * *$ & 6.62 \\
\hline Land & $1.15^{* * *}$ & 0.10 & $1.18^{* * *}$ & 0.10 \\
\hline Central & $84.63^{* * *}$ & 15.19 & $93.71^{* * *}$ & 15.23 \\
\hline East & $60.67^{* * *}$ & 21.42 & $65.34^{* * *}$ & 21.07 \\
\hline South & $83.03^{* * *}$ & 16.43 & $99.20 * * *$ & 16.79 \\
\hline Constant & $149.62 * *$ & 61.21 & $103.03 *$ & 59.22 \\
\hline Lnsigma & $6.25 * * *$ & 0.04 & & \\
\hline Lambda_Rice & $29.56^{* *}$ & 13.33 & & \\
\hline Lambda_Vegetable & $57.90^{* * *}$ & 8.29 & & \\
\hline Lambda_Specialty & $69.33^{* * *}$ & 14.58 & & \\
\hline Lambda_Grains & $-30.34^{* * *}$ & 5.17 & & \\
\hline Lambda_Other & $-23.75^{* * *}$ & 6.34 & & \\
\hline
\end{tabular}

Notes: 1. Fruit crop is the control group (base category). 2. Total obs $=9328$, Wald chi2(101) $=3232.80$, Prob $>$ chi $2<0.00013$. $^{* * *}$ and ${ }^{* *}$ denote significant at the $10 \%, 5 \%$, and $1 \%$ significance levels.

Table 4 reports both the differential coefficients for crop choice from the multinomial treatment-effects model (columns 1-2) and the ordinary least squares (OLS) model (columns 3-4). The OLS results are presented parallel with the multinomial endogenous treatment model for the purpose of highlighting the underlying key difference between the two approaches. It showcases the importance of using the multinomial treatment-effects model to address the simultaneous or correlated impact of the unobservable on both crop choices and market returns.

Although the results in columns 1-2 of Table 4 indicate the differential influence of each of the socioeconomic factors, most of the results are, in general, consistent with previous research on the determinants of farm income. Based on the results reported in columns 1-2, farm households with male, younger, and more experienced farm operators earn higher net returns on average. There are two human capital related predictors considered in this study. One is the principal operator's farming experience; the other is his or her level of education. Only the former is found to contribute positively to farm income.

The two variables involving the farm operator's characteristics, i.e., the farm operator's days of on-farm work (on an annual base) and his/her membership in farmer organizations, including farmers' associations, agricultural cooperatives, and production-marketing teams are found to exhibit a positive influence on farm income. However, the coefficient of membership in farmer organization is not significant. The results indicate that farm operators who devote more time to on-farm work obtain higher returns from farm produce. 
This result is consistent with the efficiency wage literature that work effort is positively associated with worker's remuneration (e.g., [20,21]).

Farm-household characteristics, including farm household's total labor input, size of farmland, and the geographical location of the farm household are found to be significant determinants of farm income. The two variables capturing the size of the farm in terms of either total labor or total farmland indicate the positive relationship between farm size and farm income. The results render important implications concerning economic resilience building, i.e., farms small in size are also weaker in economic resilience. The effect of geographical location is also found to be unanimous. The significant and positive coefficients for the north, central, and south areas indicate that farm households located in eastern Taiwan are comparatively weak in economic resilience.

The OLS estimates in columns 3-4 of Table 4 indicate that other crops and vegetable crops are more remunerating, with a positive net-income differential of approximately NT $\$ 521,000$ and NT $\$ 20,000$, respectively, higher than fruit crops. The other three crop choices, however, lead to lower levels of household net returns. Relative to fruit growers, growers of rice, specialty crops, and grains have lower net returns by a difference of around NT\$113,000 (rice), NT\$290,000 (specialty crops), and NT\$253,000 (grains), respectively. The OLS regression estimates thus indicate that economic resilience depends on the farm household's crop choice while holding all other income determinants constant. This result suggests that a farm household's net returns from crop produce is closely related to the choice of major crops.

Estimates and corresponding standard errors for the treatment effects are reported in columns 1-2 of Table 4. Three notable differences emerge after correcting for the endogeneity in crop choices. First, compared with the fruit growers, the treatment effect of choosing vegetables as the major crop changes from a significant positive difference into significantly negative. Second, although as predicted by the OLS estimates, growers of other crops exhibit better economic outcomes; the positive differential in net returns for these households decreases from around NT\$520,000 to NT\$498,000, whereas the negative differential for rice and specialty crop growers increases from approximately NT $\$ 113,000$ to NT $\$ 141,000$ and from NT $\$ 290,000$ to NT $\$ 354,000$, respectively. The last notable difference lies in the decrease of the negative differential for grain growers, from NT $\$ 253,000$ to NT\$224,000. The results suggest OLS will produce either upward or downward biased estimates of the economic outcome of crop choice if the endogeneity of crop choice was not explicitly taken into account.

To gain more insights into the effect of crop choice along the distribution of net returns, the results from quantile regression for the first, second, and third quartiles are reported in Table 5. Results from Table 5 indicate the net-return differentials compared to fruit crops in the lower quartile are respectively, a negative differential of NT $\$ 73,000$ for rice, a positive differential of NT $\$ 8000$ for vegetable, a negative differential of NT $\$ 240,000$ for specialty crops, a negative NT\$92,000 differential for grains, and a positive differential of $\mathrm{NT} \$ 87,000$ or other crops. The income differentials of crop choice in the second (third) quartile remain the same signs while the magnitudes are, respectively, NT\$112,000 (NT\$148,000) for rice, NT $\$ 23,000(\mathrm{NT} \$ 26,000)$ for vegetables, NT $\$ 240,000(\mathrm{NT} \$ 230,000)$ for specialty crops, NT $\$ 170,000(\mathrm{NT} \$ 260,000)$ for grains, and NT $\$ 250,000(\mathrm{NT} \$ 65,000)$ for other crops. These results confirm the persistent and increasing effect of crop choice when moving from the bottom to the top quartiles along the income distribution. 
Table 5. Quantile regression.

\begin{tabular}{|c|c|c|c|c|c|c|}
\hline \multirow{2}{*}{ Variable } & \multicolumn{2}{|c|}{ Bottom Quartile } & \multicolumn{2}{|c|}{ Median } & \multicolumn{2}{|c|}{ Top Quartile } \\
\hline & Estimate & SE & Estimate & SE & Estimate & SE \\
\hline Rice & $-73.40^{* * *}$ & 2.90 & $-112.36^{* * *}$ & 5.84 & $-148.45^{* * *}$ & 12.57 \\
\hline Vegetable & 8.17 * & 4.20 & $23.04^{* * *}$ & 5.98 & $25.74^{* *}$ & 10.29 \\
\hline Specialty & $-240.43^{* * *}$ & 4.82 & $-243.62^{* * *}$ & 10.37 & $-231.46^{* * *}$ & 15.79 \\
\hline Grains & $-92.42^{* * *}$ & 23.60 & $-167.62^{* * *}$ & 10.24 & $-260.56^{* * *}$ & 22.78 \\
\hline Other & $87.14^{* * *}$ & 19.71 & $253.03^{* * *}$ & 29.70 & $646.93^{* * *}$ & 59.78 \\
\hline Male & 488.31 & 403.12 & 795.39 & 702.54 & $4968.99^{* * *}$ & 1416.76 \\
\hline Age & 40.08 & 30.43 & $88.23^{*}$ & 51.14 & $422.54^{* * *}$ & 102.87 \\
\hline Experience & -48.73 & 31.11 & $-105.13^{* *}$ & 49.48 & $-440.98^{* * *}$ & 98.36 \\
\hline Edu2 & $1316.46^{* *}$ & 624.68 & $3280.19^{* * *}$ & 1070.23 & $12,187.98^{* * *}$ & 2155.67 \\
\hline Edu3 & 688.32 & 470.56 & $3085.57^{* * *}$ & 865.97 & $10,465.51^{* * *}$ & 1753.44 \\
\hline Edu4 & 1155.77 & 955.09 & $5419.30^{* * *}$ & 1739.32 & $19,604.13^{* * *}$ & 3556.09 \\
\hline Prior1 & -274.65 & 277.23 & $-1414.00^{* * *}$ & 488.55 & $-3218.35^{* *}$ & 826.99 \\
\hline Prior2 & -178.22 & 224.02 & $-1667.85^{* * *}$ & 397.69 & $-4749.04^{* * *}$ & 791.43 \\
\hline Prior3 & -248.87 & 198.90 & $-795.13^{* *}$ & 368.56 & $-3550.20^{* * *}$ & 751.48 \\
\hline Days & 1.07 & 4.82 & $13.32 *$ & 7.54 & 3.05 & 14.62 \\
\hline Farmer Org & 1327.30 & 825.00 & 1820.22 & 1403.24 & $10,577.99 * * *$ & 2823.04 \\
\hline HH_labor & $-220.43^{*}$ & 122.03 & -102.81 & 213.15 & $-1235.95^{* * *}$ & 425.73 \\
\hline Land & -6.18 & 4.51 & $-20.27^{* * *}$ & 6.06 & $-56.68^{* * *}$ & 11.36 \\
\hline North & $-4108.07^{* *}$ & 1724.10 & $-5595.68^{* *}$ & 2642.22 & $-24,236.34^{* * *}$ & 5164.92 \\
\hline Central & $-3951.39 *$ & 2029.49 & $-7953.08^{* * *}$ & 2766.30 & $-26,883.49 * * *$ & 5216.94 \\
\hline South & $-3938.11^{* * *}$ & 1408.70 & $-8354.96^{* * *}$ & 2394.41 & $-29,231.15^{* * *}$ & 4667.00 \\
\hline Constant & $6764.11^{* * *}$ & 2526.52 & 5565.04 & 3758.91 & $27,857.13^{* * *}$ & 7206.71 \\
\hline IMR_Crop & 56.83 & 54.75 & $195.51^{* *}$ & 90.04 & 138.99 & 171.25 \\
\hline IMR_Vegetable & $-200.09^{* *}$ & 91.82 & -166.84 & 108.31 & $-565.69 * * *$ & 181.47 \\
\hline IMR_Specialty & $-90.38^{* *}$ & 35.76 & $-234.85^{* * *}$ & 69.12 & $-728.79 * * *$ & 121.78 \\
\hline IMR_Grains & $195.66^{*}$ & 100.87 & $358.24^{* *}$ & 163.76 & $1541.01^{* * *}$ & 327.42 \\
\hline IMR_Other & 48.43 & 38.43 & $-149.63^{* *}$ & 63.79 & $-391.13^{* * *}$ & 127.13 \\
\hline
\end{tabular}

Note: ${ }^{*}, * *$ and ${ }^{* * *}$ denote significant at the $10 \%, 5 \%$, and $1 \%$ significance levels.

\section{Conclusions}

This study proposes the use of a multinomial treatment model to examine the contribution of crop choice to economic resilience. The empirical model explicitly accommodates for the endogeneity of crop choice in examining its economic outcome as measured by the farm income from crop production for the farm households. A comparison of the treatment-effect estimates with those of OLS indicate the need to take the endogeneity of crop choice into account when examining its effects on farm net returns. The causal effect of crop choices on smallholders' net returns is used to signify the contribution to economic resilience. Results from the multinomial treatment-effects model indicate the significant influence of principal operators' socioeconomic characteristics, such as gender, age, farming experience, and farm operators' days of on-farm work, on the economic resilience and farm sustainability. One research direction enlightened from our study is to add the sustainability consideration into pure economic, and perhaps, a relative short-run, perspective on net farm income when addressing the potential importance of a more diverse farming system on the long-run profitability of crop and livestock farming activities, which could be measured by various sustainability assessment indicators and its comprehensive framework [22].

The results from the multinomial treatment effects model indicate that other crops are more remunerating relative to fruit crops, whereas the net returns of households choosing all the other four crops as the major crop are significantly lower in net returns. Accordingly, among the six cash-crop categories, vegetable crops and other crops are found to be most remunerating and thus, suggests possible improvements in farm households' economic resilience through crop switching. To gain more insights into the effect of crop choice along 
the distribution of crop income, the results from the quantile regression for the first, second, and third quartiles confirm the persistent and strong effects of crop choice on net returns when moving from the bottom to the top quartiles along the income distribution. For those leading to higher returns compared to fruit crops, the effects on positive economic returns are greater. For those leading to lower returns compared to fruit crops, net returns are reduced even further along the income quartile line. These results suggest a close association of farm households' crop choices with farm income inequality among the primary farm households in Taiwan, which in turn implies possible distributional effects of crop switching since certain types of crop switching would widen the income inequality, while others may reduce the income inequality through the decrease in economic benefits when moving up the income ladder.

Author Contributions: Conceptualization, Y.-H.L.; Data curation, Y.-H.L. and Y.-C.C.; Formal analysis, Y.-H.L.; Funding acquisition, Y.-H.L.; Investigation, Y.-H.L. and S.-T.H.; Methodology, Y.-H.L.; Project administration, Y.-H.L.; Resources, Y.-H.L.; Software, Y.-H.L. and Y.-C.C.; Supervision, Y.H.L.; Validation, Y.-H.L.; Visualization, Y.-C.C.; Writing-original draft, Y.-H.L., Y.-C.C. and S.-T.H.; Writing-review \& editing, Y.-H.L. and S.-T.H. All authors have read and agreed to the published version of the manuscript.

Funding: This research was funded by the Ministry of Technology and Science (MOST) in Taiwan, grant number: MOST-106-2410-H-002-018.

Institutional Review Board Statement: Not applicable.

Informed Consent Statement: Not applicable.

Data Availability Statement: The data used in this study are available from the Survey ResearchData Archive, Center for Survey Research, Academia Sinica, through application.

Acknowledgments: This paper was presented at the 2020 Western Economic Association International (WEAI) annual conference. The authors thank the insightful comments from the discussants and the conference participants.

Conflicts of Interest: The authors declare no conflict of interest.

\section{References}

1. DAWE. Future Drought Fund Annual Report 2020-2021. Department of Agriculture, Water and the Environment. 2021. Available online: https:/ / www.awe.gov.au/sites/default/files/documents/fdf-annrep-20-21.docx (accessed on 19 November 2021).

2. Brück, T. The Welfare Effects of Farm Household Activity Choices in Post-War Mozambique; DIW Discussion Papers No. 413; German Institute for Economic Research: Berlin, Germany, 2004.

3. Adams, R.H.; He, J.J. Sources of Income Inequality and Poverty in Rural Pakistan; Research Report; International Food Policy Research Institute: Washington, DC, USA, 1995.

4. Moore, M.R.; Negri, D.H. A multicrop production model of irrigated agriculture, applied to water allocation policy of the bureau of reclamation. J. Agric. Resour. Econ. 1992, 17, 29-43.

5. Kurukulasuriya, P.; Mendelsohn, R. Modeling Endogenous Irrigation: The Impact of Climate Change on Farmers in Africa (World Bank Policy Research Working Paper 4278); CEEPA: Washington, DC, USA, 2007.

6. Kurukulasuriya, P.; Mendelsohn, R. Crop switching as a strategy for adapting to climate change. Afr. J. Agric. Resour. Econ. 2008, 2, 105-126.

7. Seo, S.N.; Mendelsohn, R. An analysis of crop choice: Adapting to climate change in South American farms. Ecol. Econ. 2008, 67, 109-116. [CrossRef]

8. Seo, S.N.; Mendelsohn, R. Measuring impacts and adaptations to climate change: A structural ricardian model of African livestock management. Agric. Econ. 2008, 38, 151-165. [CrossRef]

9. James, Z.; Julius, M. Determinants of choice of crop variety as climate change adaptation option in arid regions of Zimbabwe. Russ. J. Agric. Socio-Econ. Sci. 2013, 15, 54-62.

10. Yang, L.; Liu, M.; Lun, F.; Yuan, Z.; Zhang, Y.; Min, Q. An analysis on crops choice and its driving factors in agricultural heritage systems-a case of Honghe Hani rice terraces system. Sustainability 2017, 9, 1162. [CrossRef]

11. Ayele, M.; Emana, B.; Haji, J. Determinants of farmers' crop choices on irrigated agriculture of Halaba and Meskan districts of southern Ethiopia. J. Econ. Sustain. Dev. 2015, 6, 137-143.

12. Rahman, S. Determinants of crop choices by Bangladeshi farmers: A bivariate probit analysis. Asian J. Agric. Dev. 2008, 5, $29-41$.

13. Amare, M.; Mavrotas, G.; Edeh, H. Farmers' Crop Choice Decisions: Trends and Determinants in Nigeria and Uganda; IFPRI-Discussion Papers; International Food Policy Research Institute: Washington, DC, USA, 2018. 
14. You, L.; Spoor, M.; Ulimwengu, J.; Zhang, S. Land use change and environmental stress of wheat, rice and corn production in china. China Econ. Rev. 2011, 22, 461-473. [CrossRef]

15. Liu, Y.; Song, W.; Deng, X. Changes in crop type distribution in Zhangye city of the Heihe river basin, China. Appl. Geogr. 2016, 76, 22-36. [CrossRef]

16. Carter, M.R.; Coles, J. Inequality-reducing growth in agriculture: A market-friendly policy agenda. In Beyond Tradeoffs: Market Reform and Equitable Growth in Latin America; Birdsall, N., Graham, C.L., Sabot, R.H., Eds.; Brookings Institution Press: Washington, DC, USA, 1998; pp. 147-182.

17. Genius, M.; Pantzios, C.J.; Tzouvelekas, V. Information acquisition and adoption of organic farming practices. J. Agric. Resour. Econ. 2006, 31, 93-113.

18. Di Paolo, A. (Endogenous) occupational choices and job satisfaction among recent Spanish Phd recipients. Int. J. Manpow. 2016, 37, 511-535. [CrossRef]

19. Deb, P.; Trivedi, P.K. Maximum simulated likelihood estimation of a negative binomial regression model with multinomial endogenous treatment. Stata J. 2006, 6, 246-255. [CrossRef]

20. Shapiro, C.; Stiglitz, J.E. Equilibrium unemployment as a worker discipline device. Am. Econ. Rev. 1984, 74, 433-444.

21. Goldsmith, A.H.; Veum, J.R.; Darity, W., Jr. Working hard for the money? Efficiency wages and worker effort. J. Econ. Psychol. 2000, 21, 351-385. [CrossRef]

22. OECD. Guidance on Sustainability Impact Assessment; OECD Publishing: Paris, French, 2020; Available online: https:/ / www.oecdilibrary.org/environment/guidance-on-sustainability-impact-assessment_9789264086913-en (accessed on 11 October 2021). 